Geçici, F. (2020). Yedinci sınıf öğrencilerinin sentez metin yazma sürecindeki sorunları: Öğrenci metinlerinin ve okuma süreçlerinin analizi. Ana Dili Eğitimi Dergisi, 8(4), 1291-1310.

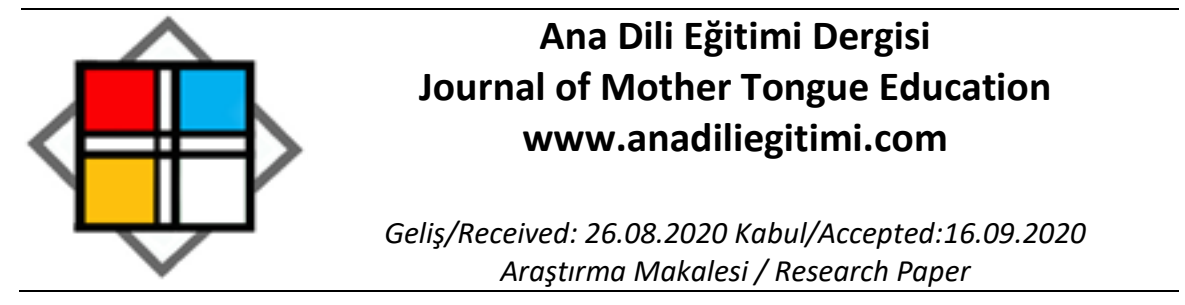

\title{
Yedinci Sınıf Öğrencilerinin Sentez Metin Yazma Sürecindeki Sorunları: Öğrenci Metinlerinin ve Okuma Süreçlerinin Analizi ${ }^{*}$
}

\author{
Fidan GEÇiCi**
}

Öz

21. yüzyılda artan bilgi birikimi ve okuryazarlık bilgisiyle birlikte çoklu kaynaklardan okuma ve anlama, kaynaklardan hareketle metin oluşturma kavramları gündeme gelmiştir. Bu kavramları içeren sentez metin yazma da yazarların birden fazla kaynaktaki bilgilerden ve ön bilgilerinden yararlanarak kendi özgün metinlerini oluşturma sürecini ifade etmektedir. Bu araştırmada 7. sınıf öğrencilerinin sentez metin yazma sürecindeki sorunlarını, oluşturdukları metinlerden, özgün metinlerini oluşturmak için yararlandıkları kaynak metinlerden ve not kâğıllarından hareketle incelemek amaçlanmıştır. Araştırmanın çalışma grubunu, Hatay il merkezindeki bir devlet okulunun 7. sınıfında öğrenim görmekte olan 51 öğrenci oluşturmaktadır. Veriler incelendiğinde, öğrencilerin yazdıkları sentez metinlerde, metnin genel organizasyonu, metin yapısı oluşturma, içerik ve anlatımı düzenleme, kaynak metinlerin kullanımı, dil kullanımına ilişkin sorunlar tespit edilmiştir. Kaynak metinlerin ve not kâğıdı kullanımının incelenmesiyle öğrencilerin okuma süreciyle ilgili eksikleri belirlenmiştir.

Anahtar Kelimeler: Yazma becerisi, sentez metin yazma, söylem sentezi, kaynaklardan yazma, okuma becerisi.

\section{Problems of Seventh Grade Students' in the Synthesis Text Writing Process: Analysis of the Students' Texts and Reading Processes}

\begin{abstract}
With the increasing knowledge and literacy knowledge of today's world, the concepts of reading and understanding from multiple sources and creating texts from sources have come to the agenda. Synthesis text creation, which includes these concepts, also refers to the process of creating authors' own original texts using information from multiple sources and prior knowledge. In this study, it is aimed to examine the problems of seventh grade students' in the synthesis text writing process based on the texts they have created, the source texts they have used to create their original texts, and the note papers. The study group of the research consists of 51 students studying in the 7th grade of a public school in the city center of Hatay. When the data are analyzed, problems related to the general organization of the text, creating the text structure, organizing the content and expression, use of the source texts, use of the language were identified in the synthesis texts written by the students. By examining the source texts and the use of note paper, students ' deficiencies regarding the reading process were determined.
\end{abstract}

Keywords: Writing skill, synthesis text writing, discourse synthesis, writing from sources, reading skill.

\footnotetext{
* Bu çalışma, Prof. Dr. Bilginer Onan danışmanlığında yazılan “Sentez Metin Yazmaya Yönelik Düzenlenen Eğitimin Yedinci Sınıf Öğrencilerinin Sentez Metin Yazma Becerilerine Etkisi" adlı doktora tezinin öntest verilerinden yararlanılarak hazırlanmıştır.

** Arş. Gör. Dr., Afyon Kocatepe Üniversitesi, Eğitim Fakültesi, Türkçe Eğitimi Ana Bilim Dalı, Afyonkarahisar, fidanugur.15@gmail.com, ORCID: 0000-0002-3336-4914
} 


\section{Giriş}

Kaynaklardan yazma eylemleri, okuma ve yazmanın birbirini etkilediği karma okuryazarlık eylemleridir (Spivey, 1990). Bu bağlamda sentez metin yazma sürecinde, okuma ve yazma becerileri eş güdümlü kullanılan becerilerdir. Dolayısıyla, sentez metin yazma sürecini değerlendirirken okuma ve yazma becerilerinin doğası da göz önünde bulundurulmalıdır.

\section{Okuma Becerisi}

Bireyin örgün eğitime başladıktan sonra geliştirmeye başladığı ilk beceri okuma becerisidir. Okuma, fizyolojik ve zihinsel unsurların bir arada kullanıldığı; harflerin, kelimelerin, sembollerin tanınması ile başlayıp bu ögelerin bütünleştirilerek anlamlandırılmasını ve yorumlama, analiz, değerlendirme, sentezleme, eleştirel düşünme gibi üst düzey bilişsel becerileri içeren karmaşık bir 'anlam kurma süreci' olarak düşünülebilir (Uğur, 2017: 201, 202). Bu sürecin 'anlama' ile sonuçlanması beklenir. Bu doğrultuda okuduğunu anlama, okur, metin, bağlam ve ön bilgi çerçevesinde gerçekleşen; okurun, bağlamdan, metinden ve önbilgilerinden etkilenerek pek çok zihinsel işlemi bir arada yürüttüğü ve bu yolla metinde verilen mesajla ilgili zihinsel bir anlam oluşturduğu süreci ifade etmektedir. Okuma becerisinin gelişmişliği, okunanların anlaşılma oranına göre değerlendirilir.

21. yüzyılda artan bilgi birikimi ve araştırma imkânlarıyla birlikte bireyler, birden çok kaynaktan bilgi edinmektedirler. Bu durum da çoklu kaynaklardan okuma ve anlamayı gündeme getirmektedir. Nitekim Goldman (2004: 319) da 1990'ların sonlarında bilişsel araştırmaların, kendi alanlarında okuyan uzmanların anlama ve eleştirel analiz becerilerine ilişkin araştırmalar ile birlikte bilgi toplumunun ortaya çıkmasıyla gündeme gelen çoklu metinlere odaklanmaya başladığını belirtmiştir. Ortaya çıkan bu tabloyla birlikte, okuma araştırmalarında birden çok metnin okunması ve anlaşıımasına yönelik yeni bir araştırma konusu gündeme gelmiştir.

Gil, Bråten, Abarca ve Strøms $\varnothing$ (2010: 157) destekleyici, tamamlayıcı veya karşıt bilgiler içeren çoklu kaynaklardan farklı konular hakkında bilgi edinmenin, birden çok kaynaklı okuryazarlık olarak adlandırılabilecek yeni bir okuryazarlık türü gerektirdiğini belirtmişlerdir. Benzer şekilde, Bråten ve Strøms $\varnothing$ (2010: 635) da birden çok metinle okuryazarlığın belli bir konunun, dersin veya durumun bütünleşik, anlamlı bir sunumunu oluşturmak ve iletmek amacıyla çeşitli bilgi kaynaklarını bulma, değerlendirme ve kullanma yeteneği ile ilgili olduğunu ifade etmişlerdir. Birden çok metni okuma ve anlama sürecinin bireylerin öğrenme ve anlama becerilerine katkısı vardır (Gil, Bråten, Abarca ve Strøms $\varnothing$, 2010; Strøms $\varnothing$, Bråten ve Samuelstuen, 2003).

Sentez metin yazma da yazma becerisiyle birlikte birden çok metnin okunması, anlaşılması ve diğer üst bilişsel becerilerden yararlanılarak kaynak metinlerin kullanımını gerektiren bir beceridir. Bu nedenle, sentez metin yazmak için çoklu kaynaklardan etkili bir biçimde yararlanmak önemlidir.

\section{Yazma Becerisi}

Illgili literatür (Göçer, 2018; Karadağ, 2016; Mather, Wendling ve Roberts, 2009; McCutchen, 2008; Tolchinsky, 2008) incelendiğinde yazmanın çeşitli şekillerde tanımlandığı görülmektedir. Literatürdeki kaynakların verdikleri bilgilerden hareketle yazma eylemi, yazma için gerekli olan psikomotor olgunluğa sahip bireylerin, belirledikleri konu hakkındaki bilgilerini, düşüncelerini, hayallerini vb. çeşitli zihinsel işlemlerden geçirerek, yazdıkları dilin harf sistemiyle ve kurallarına uygun şekilde aktarmaları olarak tanımlanabilir. Ayrıca Graham ve Harris'e (2013) göre bu sürecin, sosyal (bağlam) ve duyuşsal çeşitli faktörlerden etkilendiği de göz önünde bulundurulmalıdır.

\section{Sentez Metin Yazma}

"Sentez metin yazma"nın temeli, Spivey $(1983,1990,1997)$ tarafından ortaya atılan "söylem sentezi" kavramına dayanır. Spivey (1997: 146), söylem sentezini, yazılan metin için anlam oluşturmak amacıyla, yazarın birden çok metinden ipuçlarını kullandığı anlama ve yazma süreci olarak değerlendirmiştir. Nelson'a (2009: 545) göre de söylem sentezi, "yazarların yeni metinlerini oluştururlarken birden fazla metinsel kaynaktaki materyali birleştirmesi"dir.

Sentez metin yazma, okumaya ve okunan bilgilerden hareketle metin oluşturmaya dayanan bir süreç olduğundan özet yazmaya benzetilmektedir. Ancak sentez metinler, birden fazla kaynaktan 
bilginin seçilmesine, birleştirilmesine ve organize edilmesine dayandığı için özet yazmaktan farklıdır. Nitekim Segev-Miller (2004: 6) da söylem sentezinin özet yazmaya benzediğini, ancak bilişsel olarak özetten daha zahmetli olduğunu vurgulamaktadır.

Spivey (1990) söylem sentezini üç ana kavrama dayandırır: Seçme, organize etme ve birleştirme. Bu işlemlerle okur metinsel anlamı organize etmekte, sunmak üzere metindeki içeriği seçmekte ve metinde sunulan içerikle önceden edinilmiş bilgilerden üretilen içeriği birleştirmektedir (Spivey, 1990: 257). Aşağıda bu kavramlar hakkında kısaca bilgi verilmiştir.

\section{Organize etme}

Spivey (1990) organize etme sürecini anlatırken "Okurlar aynı zamanda yazar oldukları zaman metin organizasyonuna ne olur?" sorusunu sormuş ve süreçle ilgili açıklamasına şöyle devam etmiştir:

"Kaynaklardan hareketle yazarken yazarlar, zihinsel temsillerini biçimlendirirken ve yazdıkları metin için biçim oluştururken hem içeriği hem de ilişkileri keşfeder ve icat ederler. Sentez metin oluşturma sürecinde de yazmanın herhangi bir türünde olduğu gibi, organize etme bir anahtar ögedir. Sentez metin oluşturma sürecinde okurlar, kendi metinlerini oluşturmak için aynı zamanda yazar olurlar. Bu yazarlar genellikle farklı anlamları oluşturmak için okuduklarından dolayı, okuma araştırmalarında sıkça görülmeyen yapısal dönüşüm kanıtları görmeliyiz. Yazarlar genellikle kendi yeni metinlerini oluşturma, kendi katkılarını yapma niyetiyle metinlere yaklaşırlar (Kaufer ve Geisler, 1989'ten akt. Spivey, 1990: 265). Bu nedenle, kaynağın genel organizasyon modelini korumak, yazarlar bu seçeneğe sahip olmasına rağmen, kaynaklardan kompozisyon oluşturmada çok yaygın olmamalıdır" (s.265).

Yazarın verdiği bilgilerden hareketle, organize etmenin iyi bir okur ve iyi bir yazar olmaya dayanan bir eylem olduğu söylenebilir. Organize etmede, okuma ve yazma süreçlerinde hem okur hem yazar rolünde olan bireyin kaynaktaki bilgileri, kendi şemalarına göre dönüştürerek yeni bir sunum oluşturması söz konusudur. Benzer şekilde, Boscolo, Arfé ve Quarisa'ya (2007: 422) göre de organizasyon, seçilen içeriklerin bir metin yapısı içerisinde mantıksal ilişkilerine ve yeni metin içindeki göreceli uygunluğuna göre düzenlenmesi anlamına gelmektedir.

\section{Seçme}

Sentez metin oluşturmanın temel kavramlarından bir diğeri olan seçme, anlam oluşturmada hayati bir rol oynayan temel ve ilgili bilgilerin seçilme sürecini ifade etmektedir (Emehatsion, 1998: 56). Zhao ve Hirvela (2015: 220) ise seçmeyi "kaynaklardan önemli ve ilgili bilgilerin seçilmesi işlemi" olarak tanımlar. Yapılan tanımlardan hareketle, seçme işleminin yazma sürecinde kullanılacak bilgilerin belirlenmesiyle ilgili olduğu söylenebilir.

Emehatsion (1998: 56), seçme sürecinde yazarlardan, ana noktalar ile küçük detaylar arasında ayrım yapmalarının ve yazılan metinde tekrar ya da fazlalık olmaması için temel fikirleri ve detayları belirlemelerinin beklendiğini belirtmektedir. Bu stratejiler sayesinde, içerik için daha doğru ve önemli olan bilgiler seçilmiş olur.

\section{Birleştirme}

Spivey (1990: 276) birleştirmeyi "kişinin önceden bildikleriyle metinde açıkça belirtilen içeriği birleştirirken okurun yaptığı üretim" olarak tanımlamıştır. Spivey yazarların kaynaklardan metin yazarken metinleri, iki tür bilgi havuzundan içeriği karıştırarak oluşturduklarını ifade etmiştir: kaynak metinler ve sakladıkları bilgileri. Ona göre yazarlar, kaynaklardan seçtikleri içerikle önceden edindikleri bilgilere dayanan içeriği birbirine karıştırarak kaynak metinleri dönüştürmektedirler (Spivey, 1990: 278, 279).

Mateos ve Solé (2009: 436) de birleştirme sürecinde yazarların içeriğin az ya da çok önemli bir dönüşümüne yol açabilecek ön bilgileriyle farklı kaynaklardan içeriği birleştirdiklerini belirtmişlerdir. Sentez metin oluştururken yazarlar, dönüştürme, ilişkilendirme vb. işlemler yoluyla farklı kaynaklardaki bilgilerini ve ön bilgilerini birleştirerek özgün bir metin ortaya koyabilmektedirler. 
Kavramlardan hareketle sentez metin yazmanın, öğrencilerin aynı konudaki metinlerden edindikleri bilgileri sentezleyerek özgün bir metin oluşturma süreçlerini ifade ettiği anlaşılabilir. Öğrencilerin sentez metin yazma başarılarını artırmak için, onların yazma sürecinde ne tür sorunlar yaşadıklarını belirlemek önemlidir. Konuyla ilgili literatür incelendiğinde bu becerinin eğitimine yönelik çalışmalar (Boscolo, Arfé ve Quarisa, 2007; De La Paz ve Felton, 2010; Emehatsion, 1998; GonzálezLamas, Cuevas ve Mateos, 2016; Hammann ve Stevens, 2003; Kirkpatrick ve Klein, 2009; Luo, 2018; Martínez, Martín ve Mateos, 2011; Martínez, Mateos, Martín ve Rijlaarsdam, 2015; Mateos, Martín, Cuevas, Villalón, Martínez ve González-Lamas, 2018; Reynolds, 2006; Risemberg, 1993; Segev-Miller, 2004; Zhang 2012) ile öğrencilerin yazma performanslarını ya da süreçlerini inceleyen çalışmalar (Kirkpatrick, 2012; Mateos, Martín, Villalón ve Luna, 2008; Mateos ve Solé, 2009; Read, 2000; Spivey, 1983; Zhao ve Hirvela, 2015) yapıldığı görülmüştür. Ancak 7. sınıf öğrencilerinin sentez metin oluşturma sürecinde yaşadıkları sorunları incelemeye yönelik bir çalışmaya rastlanmamıştır.

Bu doğrultuda, bu araştırmanın amacı, 7. sınıf öğrencilerinin sentez metin yazma sürecindeki sorunlarını oluşturdukları metinlerden, özgün metinlerini oluşturmak için yararlandıkları kaynak metinlerden ve not kâğıtlarından hareketle incelemektir. Bu amaç doğrultusunda aşağıdaki sorulara cevap aranmıştır:

1. Öğrencilerin yazdıkları sentez metinlerde ne tür sorunlar bulunmaktadır?

2. Öğrenciler sentez metin oluştururken kaynak metinler üzerinde ne tür çalışmalar yapmışlardır?

3. Öğrenciler yazma sırasında ne tür not alma çalışmaları yapmışlardır?

\section{Araştırmanın Modeli}

\section{Yöntem}

Çalışmada nitel araştırma yöntemlerinden durum çalışması deseni kullanılmıştır. "Durum çalışmaları, özellikle değerlendirme süreçleri gibi birçok alanda kullanılan, araştırmacının bir durumu, sıklıkla bir programı, olayı, eylemi, süreci ya da bir veya daha fazla bireyi derinlemesine analiz ettiği bir araştırma desenidir" (Creswell, 2017: 14). Bu araştırmada da öğrencilerin sentez metin yazma sürecindeki sorunları bir durum olarak ele alınmıştır. Bu doğrultuda, öğrencilerin yazdıkları metinler ve metin yazma sürecinde yaptıkları çalışmalar incelenmiştir.

\section{Çalışma Grubu}

Araştırmanın çalışma grubunu, 2017-2018 eğitim öğretim yılında Hatay il merkezindeki bir devlet okulunun 7. sınıfında öğrenim görmekte olan 51 öğrenci oluşturmaktadır. Okulda araştırma yapılmadan önce, Hatay Valiliği, Hatay il Millî Eğitim Müdürlüğü, okul müdürlüğü ve öğrenci velilerinden gerekli izinler yazılı olarak alınmıştır.

\section{Verilerin Toplanması}

Veri toplama sürecinde, öğrencilere dinozorların özellikleri hakkında bilgi veren iki bilgilendirici metin sunulmuştur. Öğrencilerden bu iki metindeki bilgilerden yararlanarak aynı konuda kendi özgün metinlerini oluşturmaları istenmiştir. Ayrıca eğer isterlerse okuma ve yazma süreçlerinde kullanmak üzere istedikleri kadar ek kâğıt alabilecekleri de belirtilmiştir. Bu uygulama için öğrencilere 2 ders saati zaman verilmiştir.

\section{Verilerin Analizi}

Verilerin analiz edilmesinde doküman incelemesi yönteminden yararlanılmıştır. Doküman incelemesi, "araştırılması hedeflenen olgu veya olgular hakkında bilgi içeren yazılı materyallerin analizini kapsar" (Yıldırım ve Şimşek, 2016: 189). Araştırmada analiz edilmesi planlanan dokümanlar şöyledir:

1. Öğrenciler tarafından yazılan sentez metinler: Bu metinler, dinozorların özellikleri konusunda yazılmış, bilgilendirici türde metinlerdir.

2. Kaynak metinler: Kaynak metin olarak kullanılan okuma metinlerinden biri "Dinozorların Dünyası" (Can, 2012) başlıklı metindir. Metnin asıl hâli çalışmaya uygun şekilde 
düzenlenmiştir. Metnin düzenlenmiş ve çalışmada kullanılan şekli 314 kelimeden oluşmaktadır. Kaynak metin olarak kullanılan metinlerden diğeri “Geçmişin Gerçek 'Dev'leri Dinozorlar" (Tok, 1998) başlıklı metindir. Bu metnin asıl hâli de çalışmaya uygun şekilde düzenlenmiştir. Metnin düzenlenmiş ve çalışmada kullanılan şekli 499 kelimeden oluşmaktadır.

3. Öğrencilerin not kâğıtları: Öğrencilerin okuma sırasında oluşturdukları, yazmada yararlanmak üzere aldıkları notları içeren kâğıtlardır.

$\mathrm{Bu}$ araştırmada doküman incelemesinden aşağıdaki hususlara ilişkin veri toplamak amacıyla yararlanılmıştır:

1. Öğrencilerin yazdıkları metinlerde metnin genel organizasyonu, metin yapısı oluşturma, içerik ve anlatımı düzenleme, kaynak metinlerin kullanımı ve dil kullanımıyla ilgili sorunlarını tespit etmek,

2. Kaynak metinlerdeki yazım ve işaretlemelerden hareketle okuma süreçlerini incelemek,

3. Not kâğıtlarından hareketle metne hazırlık süreçleriyle ilgili fikir yürütmek.

Bu doğrultuda veri analizi süreci şöyle gerçekleşmiştir:

Sentez metinler analiz edilmeden önce, ilgili literatür (Asención, 2004; Beal, 2010; Emehatsion, 1998; Gebril, 2006; Holmberg, 1998; Kim, 2008; Martínez, Mateos, Martín ve Rijlaarsdam, 2015; Mateos, Martín, Villalón ve Luna, 2008; Mateos ve Solé, 2009; McMackin, 1994; Nash, 1990; Reynolds, 2006; Risemberg, 1993; Schlumberger, 1991; Solé, Miras, Castells, Espino ve Minguela, 2013; Watanabe, 2001; Zhang, 2012) taranarak alanda kullanılan rubrikler ve sentez metinleri değerlendirmeye yönelik kullanılan yöntemler incelenmiştir. Bu doğrultuda metinlerde incelenecek boyutlar, metnin genel organizasyonu, metin yapısı oluşturma, içerik ve anlatımı düzenleme, kaynak metinlerin kullanımı ve dil kullanımı olarak belirlenmiştir. Analiz sırasında bu boyutlara yönelik olarak belirlenen sorunlar ayrı ayrı kaydedilmiştir.

Ek olarak, belirlenen sorunlar detaylandırılarak ifade edilmiştir. Örneğin, öğrencinin metinde ele alınanları toparlayıcı, işlevine uygun bir sonuç yazamadığı tespit edilmişse, bu sorunun kaynağının ne olduğu, sonucun neden işlevine uygun olmadığı açık bir şekilde ifade edilmeye çalışılmıştır. Her boyutla ilgili belirlenen sorunlar listelenerek, kaç öğrencide bu sorunla karşılaşıldığına ilişkin frekans değerleri verilmiştir.

Kaynak metinlerin analizine başlanmadan önce, okuma sürecinde kullanılabilecek teknikler belirlenmiştir. Buna göre doküman incelemesinde temel alınan ölçütler şöyledir:

1. Önemli noktaların altını çizme

2. Önemli kelime ve kavramları yuvarlak içine alma

3. İşaretlemelerden yararlanma

4. Önemli bölümlerden notlar alma/Metnin kenar boşluklarına notlar alma

Okuma metinlerinde bu ölçütler dışında herhangi bir uygulamaya rastlanırsa bunun da kaydedilmesi planlanmıştır. Bu hususlarla ilgili olarak okuma metinleri ayrıntılı bir biçimde analiz edilmiştir. Öğrencilerin uygulamaları listelenmiş ve frekans değerleri verilmiştir.

Not kâğıtlarına, öğrencilerin yazma sürecine hazırlanırken nasıl not aldıklarını belirlemeye yönelik olarak doküman incelemesi yapılması planlanmıştır. Analize başlanmadan önce notların hangi açılardan değerlendirilmesi gerektiği üzerinde durulmuştur. Bununla ilgili olarak, metinlerde kullanılacak bilgilerin nasıl not edildiği, içerik ve metin organizasyonunu planlamak adına ne tür uygulamaların yapıldı̆̆ının incelenmesine karar verilmiştir.

\section{Geçerlik ve Güvenirlik}

Analizin güvenilirliğini sağlamak için kodlamalar bir kez yapıldıktan sonra, veriler ve kodlamalar tekrar gözden geçirilmiş, kararsılık durumlarında Türkçe eğitimi alan uzmanı olan bir öğretim elemanıyla uzman değerlendirme toplantısı yapılarak ifadeler düzenlenmiştir. Verilerin, çalışma kapsamında belirlenmiş kavramsal çerçeveye uygun olarak toplanmasına ve yine bu çerçeveye göre analiz edilmesine özen gösterilmiştir. Ayrıca veri toplama ve analiz aşmaları ayrıntılı bir biçimde sunulmaya çalışıımıştır. 
Çalışmada geçerliğin sağlanması için doküman incelemesinden elde edilen veriler tekrar tekrar değerlendirilerek, sonuçlara nasıl ulaşıı dığı çeşitli örneklerden hareketle açık bir biçimde sunulmaya çalışılmıştır. Ayrıca dokümanlara ilişkin bulgular ayrıntılı bir biçimde aktarılmıştır.

\section{Bulgular}

\section{Metnin Genel Organizasyonundaki Sorunlara ilişkin Bulgular}

Incelenen metinlerde metnin genel organizasyonu boyutuyla ilgili belirlenen sorunlar şöyledir:

Giriş bölümüyle ilgili olarak öğrencilerden bazılarının içerik ve/ya da biçimsel açıdan giriş bölümünü karşılayan bir başlangıç yapmadığı $(f=17)$ tespit edilmiştir. Giriş bölümü bulunan metinlerde ise tek cümleyle giriş yapma $(f=2)$, girişte metnin bağlamına uymayan ifadeler kullanma $(f=1)$, bilgilendirici metin niteliğine uygun olmayan bir giriş yapma $(f=2)$, girişte sonuç ifadelerine yer verme $(f=1)$, giriş işlevini tam olarak karşılamayan ancak konuya hazırlayıcı bir nitelik taşıyan giriş yapma $(f=5)$, doğrudan bilgi anlatımıyla giriş yapma $(f=21)$ ve kaynak metnin giriş bölümüne öykünme $(f=5)$ sorunları tespit edilmiştir. Aşağıda bilgilendirici metin niteliğine uygun olmayan bir giriş örneği bulunmaktadır.

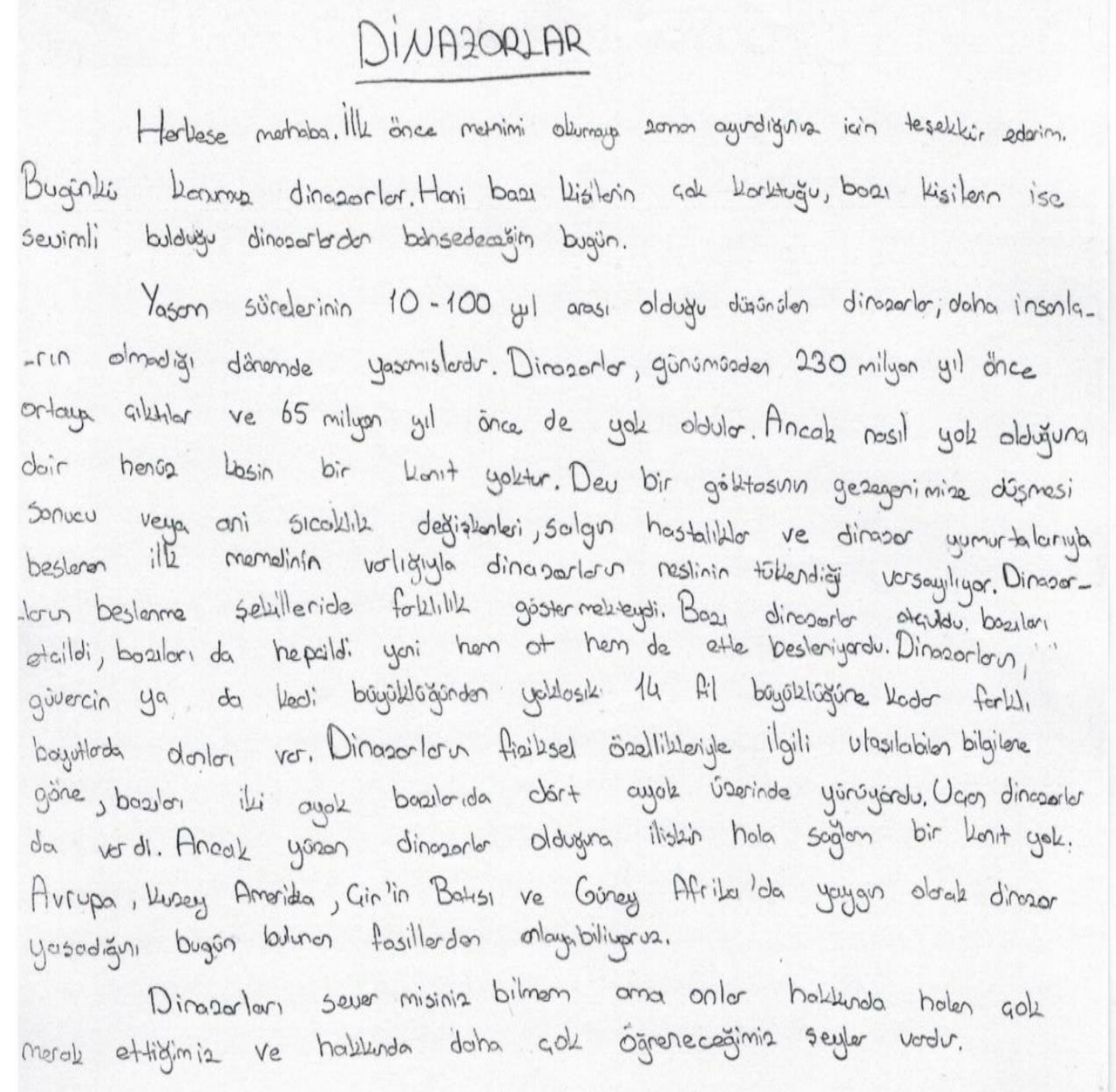

Şekil 1. Bilgilendirici Metin Niteliğine Uygun Olmayan Giriş Örneği

Şekil 1'deki giriş incelendiğinde, öğrencinin metne konuşma üslubuyla başladığı, devamında ise bilimsel bir anlatım tarzı kullandığı dikkat çekmektedir. Bu anlamda giriş, metnin genel anlatım tarzına ve niteliğine uygun değildir. 
Gelişme bölümünde tespit edilen sorunlar şöyledir: Konuyu çok az detaylandırma ( $\mathrm{f}=45)$, bir paragrafta farklı boyutlarla ilgili bilgi sunma $(f=48)$, tutarsız bir gelişme bölümü yazma $(f=49)$ ve kısmen tutarlı bir gelişme bölümü yazma ( $f=1)$. Şekil 2 'de tutarsız bir gelişme bölümü örneği görülmektedir:

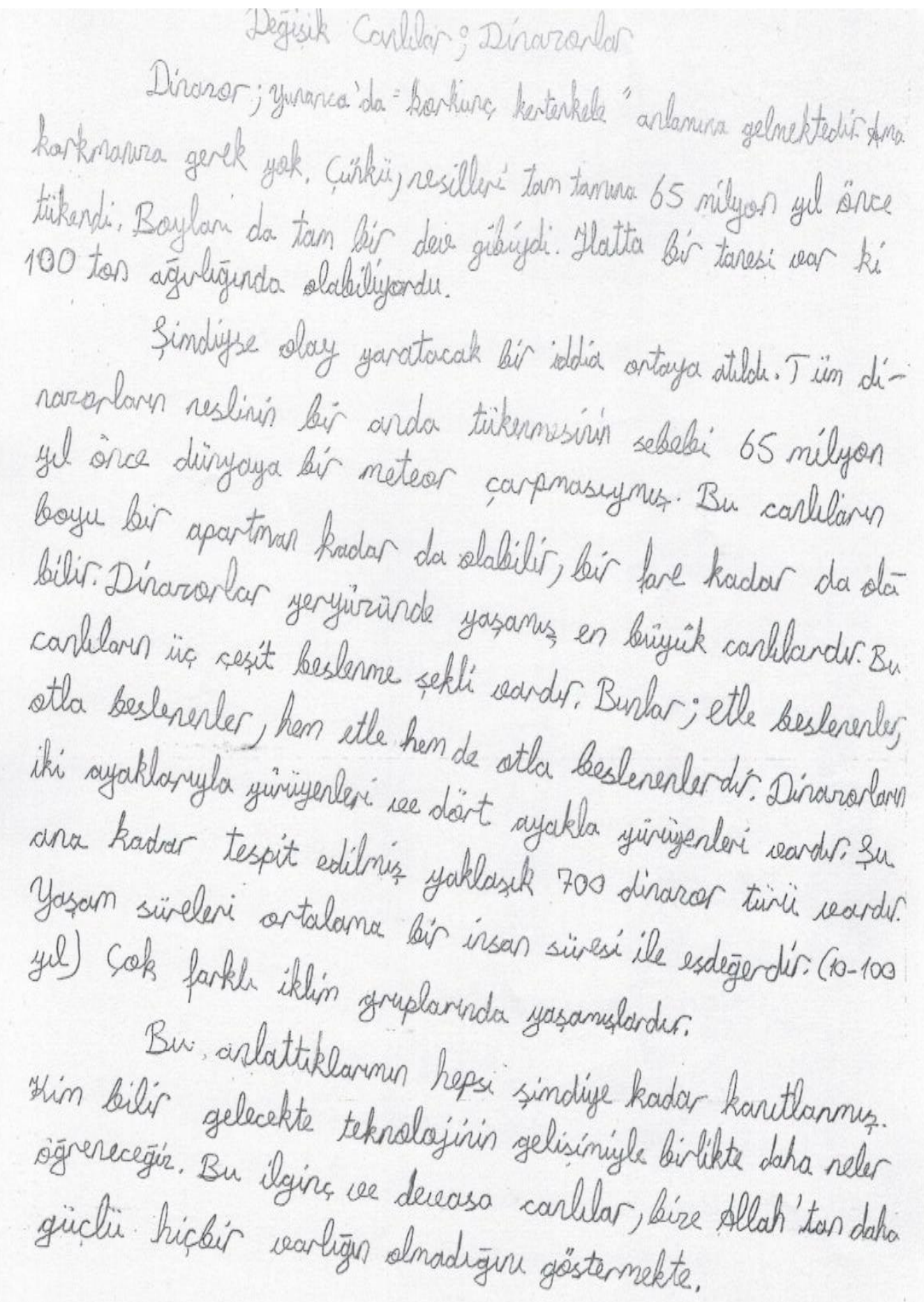

Şekil 2. Tutarsız Bir Gelişme Bölümü Örneği

Şekil 2 incelendiğinde, öğrencinin, gelişme bölümündeki anlatımında tutarlı bir seyrinin olmadığı, birbiriyle bağlantılı olmayan farklı boyutları art arda sıraladığı dikkat çekmektedir.

Metinlerin sonuç bölümleri incelendiğinde, bazı öğrencilerin sonuç yazmadığı $(f=21)$ tespit edilmiştir. Bunun yanı sıra öğrencilerin metinde ele alınanları toparlayıcı, işlevine uygun bir sonuç yazamadıkları da görülmüştür. Bununla ilgili olarak, gelişme bölümünde verilmesi gereken bilgileri sonuçta verme $(f=18)$, konuyla ilgili tahmin, öneri, mesaj, kişisel yorum vb. sonuç ifadelerine tek 
cümlede yer verme $(f=11)$, sonucu kaynak metnin sonucundan kopyalama $(f=4)$, kaynak metnin/metinlerin sonucuna öykünme $(f=3)$, sonuçta metnin bağlamına uymayan ifadeler kullanma $(f=5)$ sorunları tespit edilmiştir. Aşağıdaki şekilde gelişme bölümünde verilmesi gereken bilgileri sonuçta veren ve sonuçta metnin bağlamına uygun olmayan ifadeler kullanılan bir metin örneği görülmektedir:

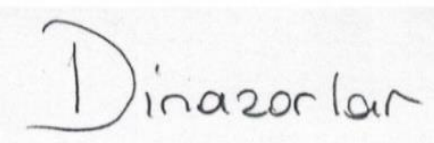

Dinazorlara iyi bakmanizi öneririm. Dinazorlorin'da

conları vordr. Bir dinazor aok eskiden yosomis colk bü̈ük

Kertenkele sürüngentere verilen ortak adidir. Korkuna Kertenkele

Bazen korkna gelirler bazen sovimk:

Bu özellikleriyle dinazerlar yüríyen aportmontar gibíydicer.

Dinazorlorin 4 ayaklari ya da 2 ayaklor, da vorder.

Hayvanin boyu 46 metreydi. Bu bü̈uklük bir futbel sahasinin yaklasik yorisı kador dir. 100 tona yaken bir agirligi olduğu

(sismosoros) adi yakistrilmis. En son dinazorun da

ölmesinden bu yana yaklasik altmis bes milyon yil geati.

Hayuonlari ve dinazorlari da seumeliyiz...

Bu dinazorlarinda akrabaleri varmis akrabaleri timsahlarin ve Kuslarin atalariyla akrabaydilar. Dinazorlarin bestenme sekilleri Fesitlilik göstermekteydi. Bazi dinazorlor ot la, etle ve hem ot hem de etle beslenen dinozor tülleri bulunmaktayd. Aurupa, kuzay

Amerika, Ginlin batist ve Güney Afrika' da yaygin dorak dinow yosadigni bü̈̈n bulunon fosillerden gnloriz.

Hayuonlari dinozorlare da Seumeliyiz.

Şekil 3. Gelişme Bölümünde Verilmesi Gereken Bilgileri Sonuçta Verme ve Sonuçta Metnin Bağlamına Uygun Olmayan ifadeler Kullanma Sorunları

Şekil 3 incelendiğinde, öğrencinin son paragrafı gelişme bölümünün devamı şeklinde yazdığı ve metnin en son cümlesinde bağlama uymayan bir ifadeyle metni sonlandırdığı dikkat çekmektedir.

Giriş, gelişme ve sonuç bölümlerinin organizasyonuyla ilgili olarak giriş, gelişme ve sonuç bölümleri için ayrı paragraflar oluşturmama $(\mathrm{f}=18)$ ve giriş, gelişme ve sonuç bölümleri arasında tutarlı bir bağlantı kuramama $(\mathrm{f}=30)$ sorunları tespit edilmiştir. Aşağıda bölümleri arasında tutarlııı ve organizasyon sorunları olan bir metin örneği görülmektedir. 


\section{Dinzorlor}

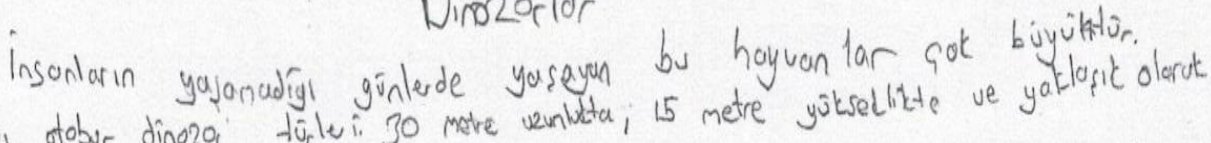

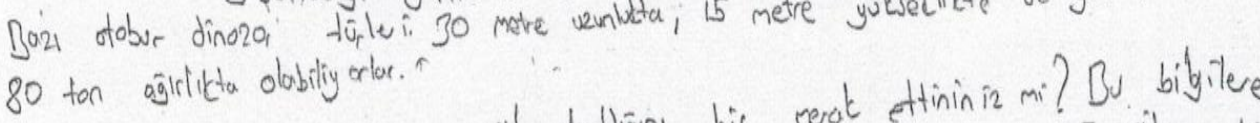

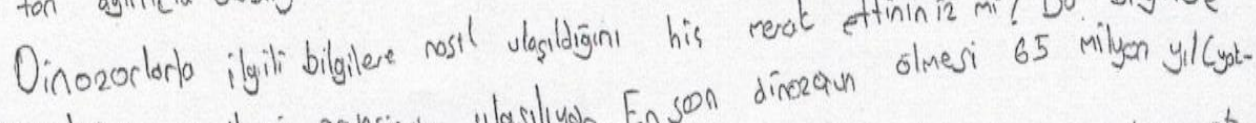

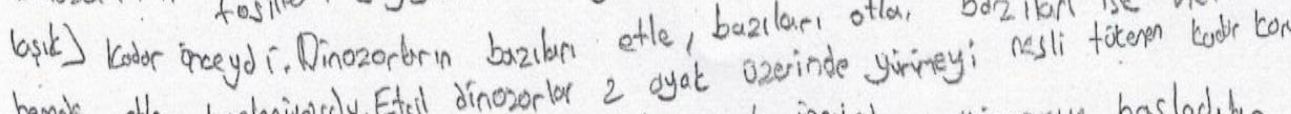

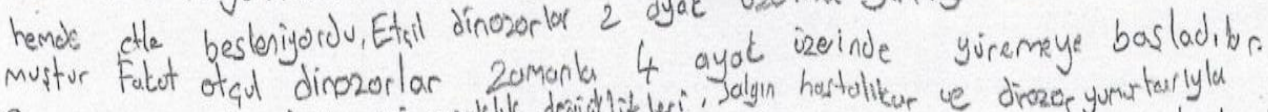

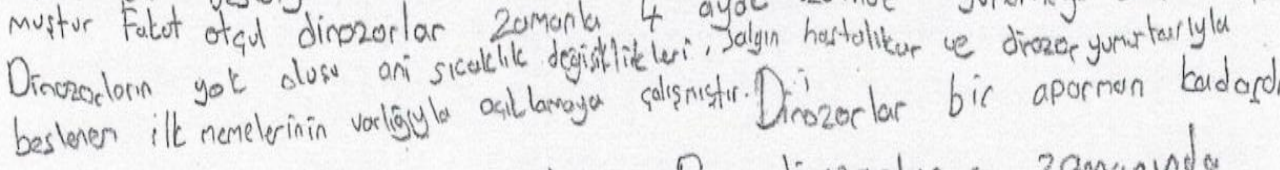
yosumak cot isterdim Güno oniar got merak edyorum.

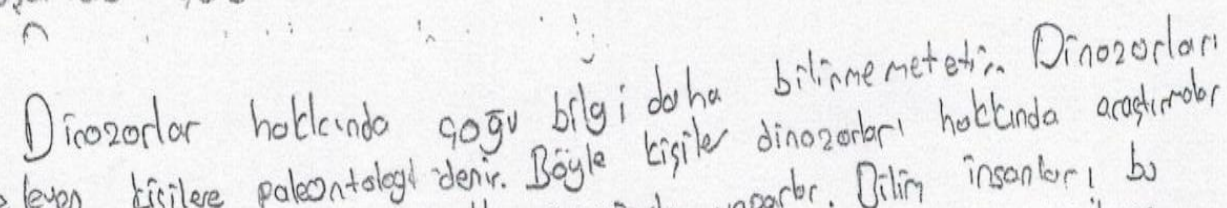

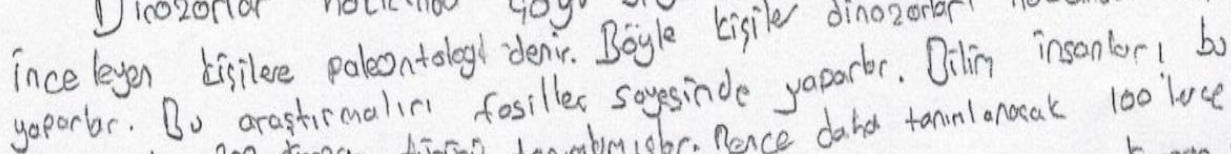

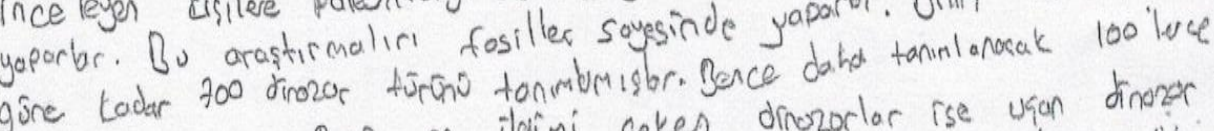
dinozor tor wr. Berim en ilgimi aeken drnozorlar ise ugan dinoger turter. Bu dinzabare ornet darat. Arsupteritsdiribaz dinozor lar ith

Şekil 4. Giriş, Gelişme ve Sonuç Bölümlerinin Organizasyonunda Problem Bulunan Bir Öğrenci Metni Örneği

Şekil 4 incelendiğinde, öğrencinin metnin bölümlerini işlevlerine uygun oluşturamadığı görülmektedir. Bu durum, hem bölümlerin kendi içindeki organizasyonuna hem de metnin bütününün organizasyonuna zarar vermiştir.

Metinlerin başlıkları incelendiğinde, 2 öğrencinin başık yazmadığı, bir öğrencinin de anlamsız bir başlık yazdığı tespit edilmiştir. Gruptaki öğrencilerin büyük çoğunluğunda ( $f=44)$ özgün bir başlık yazamama sorunu vardır. Bir öğrencide de içeriğe uygun başıık yazamama sorunu tespit edilmiştir.

\section{Metin Yapısı Oluşturmadaki Sorunlara İlişkin Bulgular}

Incelenen metinlerde metin yapısı oluşturma boyutuyla ilgili belirlenen sorunlar şöyledir:

Metni oluştururken 6 öğrenci kaynak metinlerdeki temel düşüncelerden hiç yararlanmamış, 32 öğrenci ise çok az yararlanmıştır. Bunun yanı sıra öğrencilerden pek çoğu metin yapısı oluştururken, temel düşünceler dışındaki destekleyici düşüncelere oldukça az yer vermişlerdir. Bu noktada öğrencilerin bir metinde yararlandığı metin yapısı türleri şöyle belirlenmiştir:

Sadece açıklamadan yararlanma ( $f=6)$, açıklama ve sınıflamadan yararlanma ( $f=20)$, açıklama, sınıflama ve sebep sonuç yapılarından yararlanma $(f=8)$, açıklama, tanımlama, sınıflama ve sebep sonuç yapılarından yararlanma $(f=2)$, açıklama ve sebep sonuç yapılarından yararlanma $(f=2)$, açıklama, karşılaştırma, sebep sonuç ve sınıflamadan yararlanma $(\mathrm{f}=1)$, tanımlama, açıklama, sınıflama yapılarından yararlanma $(f=3)$, açıklama ve karşılaştırma yapılarından yararlanma $(f=1)$, açıklama, örnekleme ve sınıflama yapılarından yararlanma $(f=6)$, açıklama, tanımlama, örnekleme ve sınıflama yapılarından yararlanma $(\mathrm{f}=2)$. Bu durum öğrencilerden bazılarının farklı yapıları bir arada 
kullanabilmesine rağmen metin yapısını yeterince geliştiremediğini göstermektedir. Şekil 5'te açıklama ve sınıflama yapılarından yararlanılarak oluşturulmuş bir metin örneği görülmektedir:

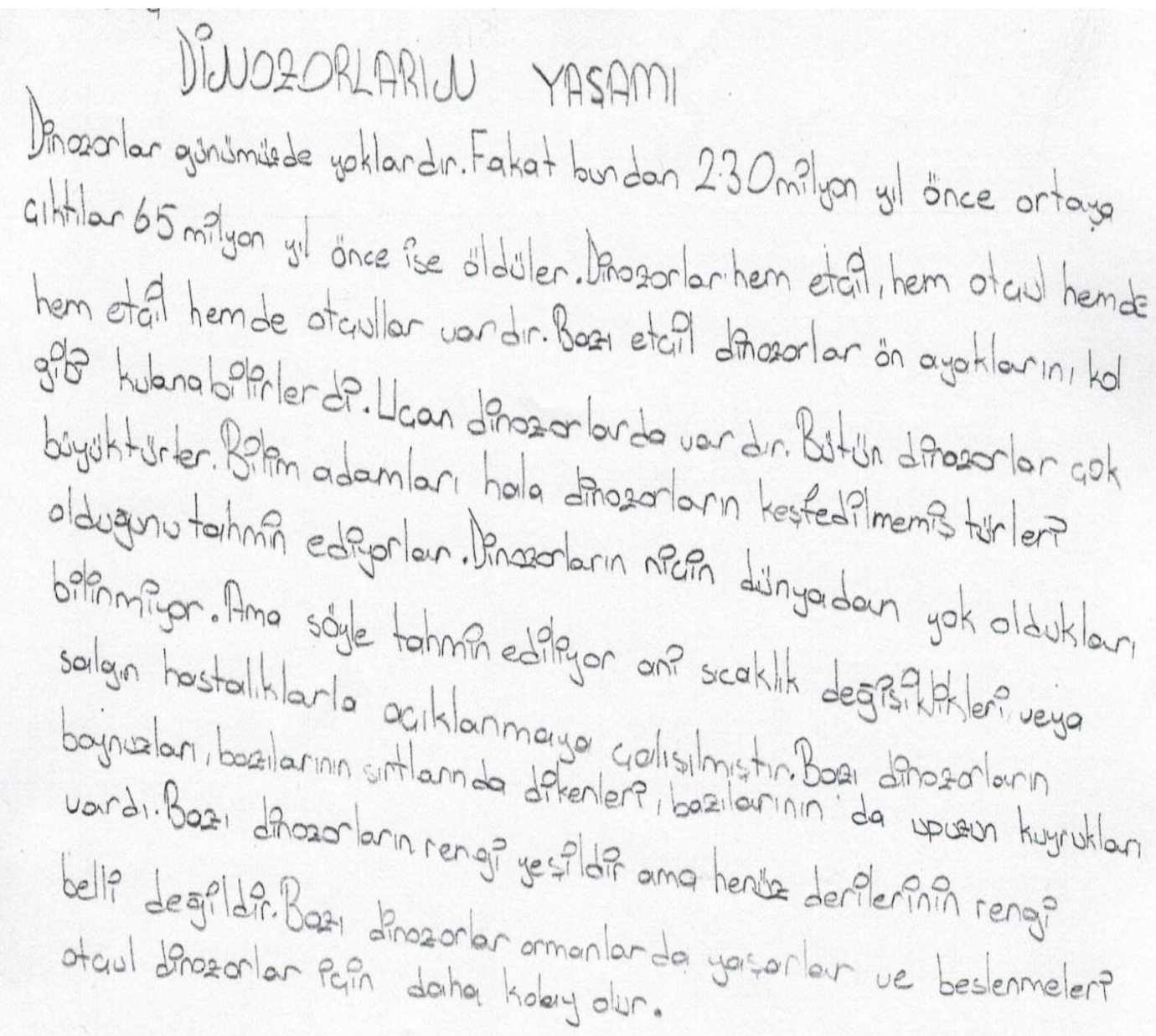

Şekil 5. Açıklama ve Sınıflama Yapılarından Yararlanılarak Oluşturulmuş Bir Metin Örneği

Şekil 5 incelendiğinde, öğrencinin anlatımında iki ayrı bilgilendirici metin yapısı özelliğine yer verdiği görülmektedir. Öğrenci, açıklama ve sınıflamalarla birtakım bilgiler aktarsa da, bu yapıları gelişmiş bir düzen içinde sunamamaktadır.

\section{İçerik ve Anlatımı Düzenlemedeki Sorunlara İlişkin Bulgular}

Metinler içerik ve anlatımı düzenleme boyutu açısından incelendiğinde, sorunların kaynak metinlerdeki bilgilerin aktarımı, tutarlıık ve üslup açısından ortaya çıktığı görülmüştür.

Kaynak metinlerdeki bilgilerin aktarımıyla ilgili olarak tespit edilen sorunlara bakıldığında öğrencilerden bazılarııın kaynak metinlerden aldığı bilgilerin tamamını kopyalayarak $(f=3)$, bir kısmının bazılarını kopyalayarak ( $f=12)$, bir kısmının da aldığı bilgilerin büyük çoğunluğunu kopyalayarak $(f=3)$ metin oluşturduğu görülmüştür. Buna ek olarak, öğrencilerin neredeyse tamamının metinden alınan bilgileri mantıklı bir sırayla sunamadığı $(f=50)$, bir öğrencinin de bilgi sunumunda kısmen tutarlılık sergilediği görülmüştür. Kaynak metinlerdeki bilginin aktarımında yorum yapmama $(f=40)$, bilgi/düşünce tekrarı yapma $(\mathrm{f}=10)$ ve bazı bilgileri anlaşılır biçimde sunamama $(\mathrm{f}=4)$ bu başlıkta tespit edilen diğer sorunlardır.

Metnin tutarlılı̆ı̆yla ilgili olarak, bilgi ve düşünceler arasında yönlendirici sözcüklere hiç yer vermeme $(f=30)$ ya da oldukça az yer verme $(f=20)$, bilgi ve düşünceler arasında bağlantı cümleleri kullanmama $(f=35)$ ya da oldukça az kullanma $(f=16)$, bazı cümleler arasında tutarlı bağlantılar kuramama ( $f=46)$, kendi içinde tutarsız paragraflar oluşturma $(f=39)$ ve birbiriyle çelişen bilgilere yer 
verme $(f=1)$ sorunları tespit edilmiştir. Aşağıda yönlendirici sözcüklere ve bağlantı cümlelerine yeterince yer vermeyen bir öğrencinin metni görülmektedir:

\section{- DINGZORLAK-}

Dirazorlar geamiste josamis büyuk conlilardir. Qinazor ismi onlara eski. Yununcodoki "deinos" ve "sauros" säzcükleridén gelmektedir Türka anlami" Korkun a kertenkeh anlaimna gelir Bu canlilarin yosama sureleri $10-100$ yil arasinda degisim gostermelta

Qinazerlar bizden 230 mityon yil önce artaya ailtilar ve 65 milyon yil once de yok oldular. Bilim insantar dunyada 700 tone dinazor türü oldyganu tahmin ediycri Dinazorlarm bozllan iki bozslari ise dort qyak istünde yürüyorlar. Bunlarin disinda ucan dinuzorlar da vardir. Bazi dinazorlarn kendilerini dis etkenterden korumak icin bayunlarmi, sirtlarindaki dikenleri bazilarida upuzun kuyruklarini kullanir- Beslenme sekiller

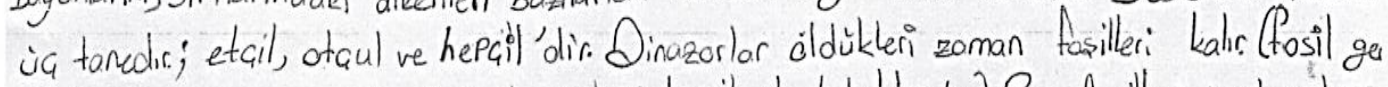
miste yasamis ve sonrada ömus hayvonlarin kenilk vb. kalintllaridir.). Bu fosilleri inceleyentere Paleontoloa denir. (Paleontolog áck eski cağlarda yasamis conliları inceleyen bilim dalidi.) Bazi bilim insanlaring göre bazi otoburlar 30 metre uzunlult, 15 metre yulselliginde ve 80 ton agirligindadir. Buna ïnek darak $A B Q^{\prime}$ de bulunan bir dinazerun omuz kemigi 2,5 metre, bay un kemigi; ise 1, 4 metreymis. Bu dinazor bir futbol sahasinin yarisi kadarms.ve bayu lib metre, agirligi ise 100 tonmus. Bilim odamlari ona "Seismosaurus" adini yakistirnistr. Turkae anlami "Depremozor"dur.

Qinasorbarin ölim nedenteri's ani sicaklk degissimi, solgin nastaliklar, dinazor yumurtaları diger meneliter tarafindan yenmesi veya yok olmasi, dinyaya gok ta\$s carpmasi gibi tahminkerd yok oldukları tahmin edilmektedic.

Şekil 6. Yönlendirici Sözcükler ve Bağlantı Cümleleri Kullanmakta Sorun Yaşayan Bir Öğrenci Metni

Şekil 6’da öğrencinin cümleler arası tutarlı bağlantılar yapmayı sağlayan yönlendirici sözcükleri ve bağlantı cümleleri kullanmadan, anlamca ilgisiz cümleleri art arda sıraladığı dikkat çekmektedir.

Üslupla bağlantılı olarak bazı öğrencilerin, metinde yer yer bilgilendirici metin anlatım dilinden uzaklaştıkları $(f=6)$ bazı öğrencilerin de metni bilgilendirici metin üslubuyla yazamadıkları $(f=4)$ görülmüştür. Ayrıca bazı öğrencilerde $(f=7)$ akademik dil ile olay anlatımı dilini birlikte kullanma (...tir... mış) sorunu tespit edilmiştir.

\section{Kaynak Metinlerin Kullanımındaki Sorunlara İlişkin Bulgular}

Metinler, kaynak metinlerin kullanımı açısından değerlendirildiğinde, sorunların bilgi seçimi ve kaynak metinlerdeki bilgilerin kullanım şekli başlıklarında ortaya çıktığı görülmüştür.

Bilgi seçimiyle ilgili olarak, kaynak metinlerden konuyla ilgili önemli bilgileri seçememe/ayrıntılara yer verme $(f=5)$, ya da oldukça az önemli bilgi seçme $(f=34)$ ve konunun az sayıda boyutuyla ilgili bilgi verme $(f=39)$ sorunları tespit edilmiştir. Aşağıda metni için önemli bilgileri seçememe ve ayrıntı bilgilerle metin oluşturma sorunu yaşayan bir öğrencinin metni örnek olarak verilmiştir: 


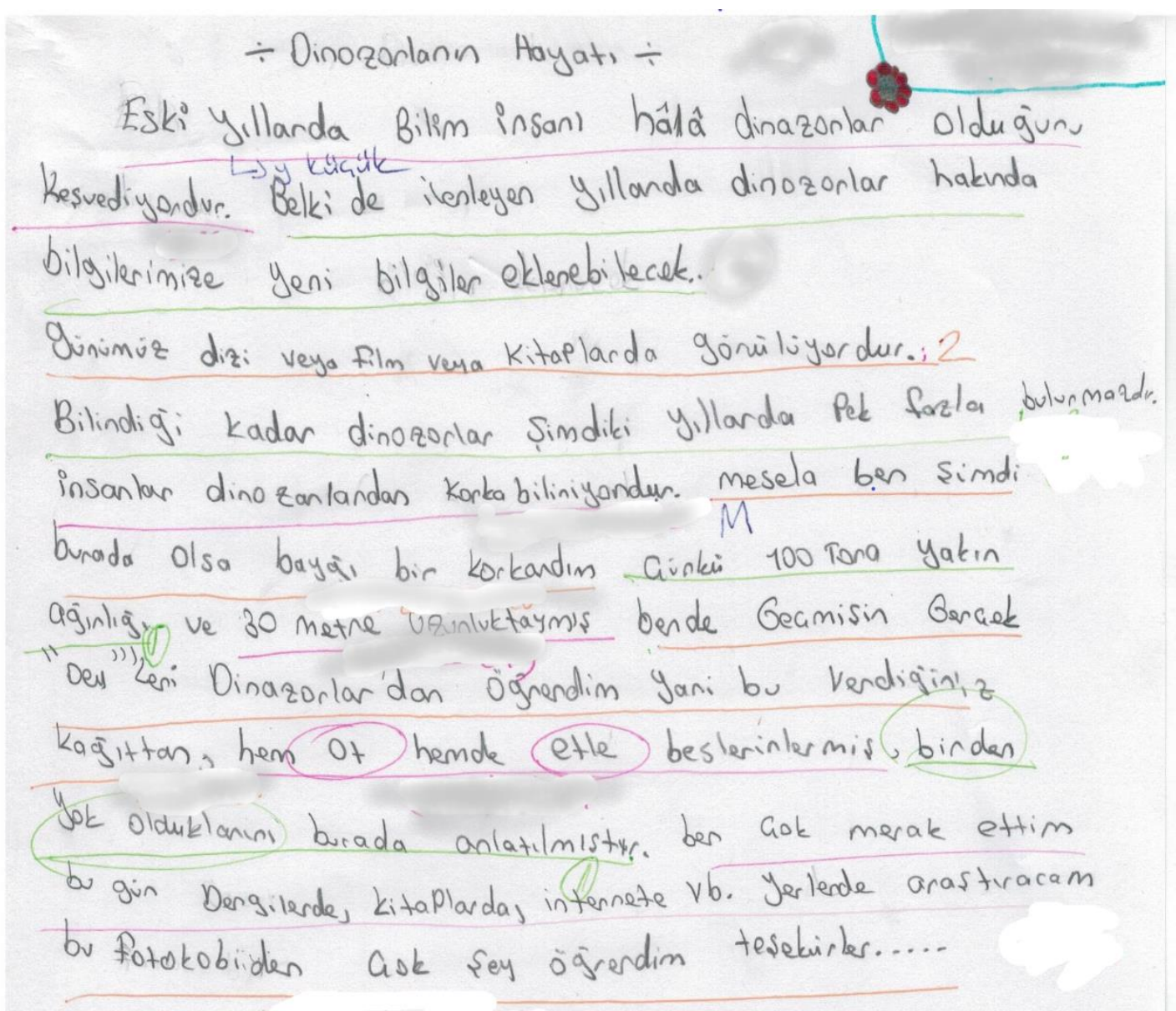

Şekil 7. Kaynak Metinlerden Konuyla İlgili Önemli Bilgileri Seçememe/Ayrıntılara Yer Verme Sorunu Olan Bir Metin Örneği

Şekil 7'de öğrencinin metne yön veren asıl bilgiler yerine, bu bilgileri destekleyen ya da örnekleyen bilgilerle ve kendi yorumlarıyla metin oluşturduğu görülmektedir.

Seçilen bilgilerin, özgün metinlerde kullanımında ise en çok karşılaşılan sorun bir temel düşünce etrafında şekillenen paragraflar oluşturamama $(f=50)$ olmuştur. Bunun yanı sıra, kaynak metinlerden alınan bilgilerden büyük çoğunluğunu $(f=3)$ ya da bazılarını $(f=38)$ eksik ya da yanlış aktarma, kaynak metinlerdeki bilgileri kendi bilgi/düşünceleriyle detaylandırmama ( $f=39$ ) ya da kısmen detaylandırma $(f=3)$ ve kaynak metinlerdeki ilgili bilgileri ilişkilendirememe ( $f=47$ ) sorunlarıyla karşılaşılmıştır.

\section{Dil Kullanımındaki Sorunlara iliş̧in Bulgular}

Metinler dil kullanımı açısından incelendiğinde, cümle anlamı, anlatım bozuklukları, yazım ve noktalama kurallarıyla ilgili hatalar tespit edilmiştir. Cümle hataları konusunda tespit edilen sorunlar şöyledir: Cümle anlamını tam kuramama $(f=8)$, gereksiz bağlaç kullanımı $(f=1)$, cümlenin yüklemini eksik yazma $(f=2)$ ve uzun cümle kurma nedeniyle anlamı oluşturamama $(f=2)$.

Metinlerde karşılaşılan anlatım bozuklukları ise fiilde çatı hatasından $(f=6)$, özne-yüklem uyumsuzluğundan $(f=1)$, eksik ek kullanımından $(f=8)$, tamlayan eki eksikliğinden $(f=1)$, tamlanan eki fazlalığından $(f=1)$, eksik ifadeden $(f=4)$, yanlış kelime kullanımından $(f=3)$, gereksiz kelime kullanımından $(f=6)$ ve nesne eksikliğinden $(f=1)$ kaynaklanmaktadır.

En sık karşılaşılan yazım hataları ayrı yazılması gereken bağlaçları birleşik yazma ( $f=30$ ) ve küçük harfle yazılması gereken yerde büyük harfle yazmadır $(f=19)$. Bunun yanında, cümleye küçük harfle başlama ( $f=12)$, özel isimleri küçük harfle yazma $(f=12)$, kelimeyi yanlış yazma $(f=10)$ ve heceyi yanlı̧ bölme $(f=4)$ hataları da tespit edilmiştir. Aşağıda ayrı yazılması gereken bağlaçları birleşik yazma sorunu olan bir öğrencinin metni görülmektedir: 


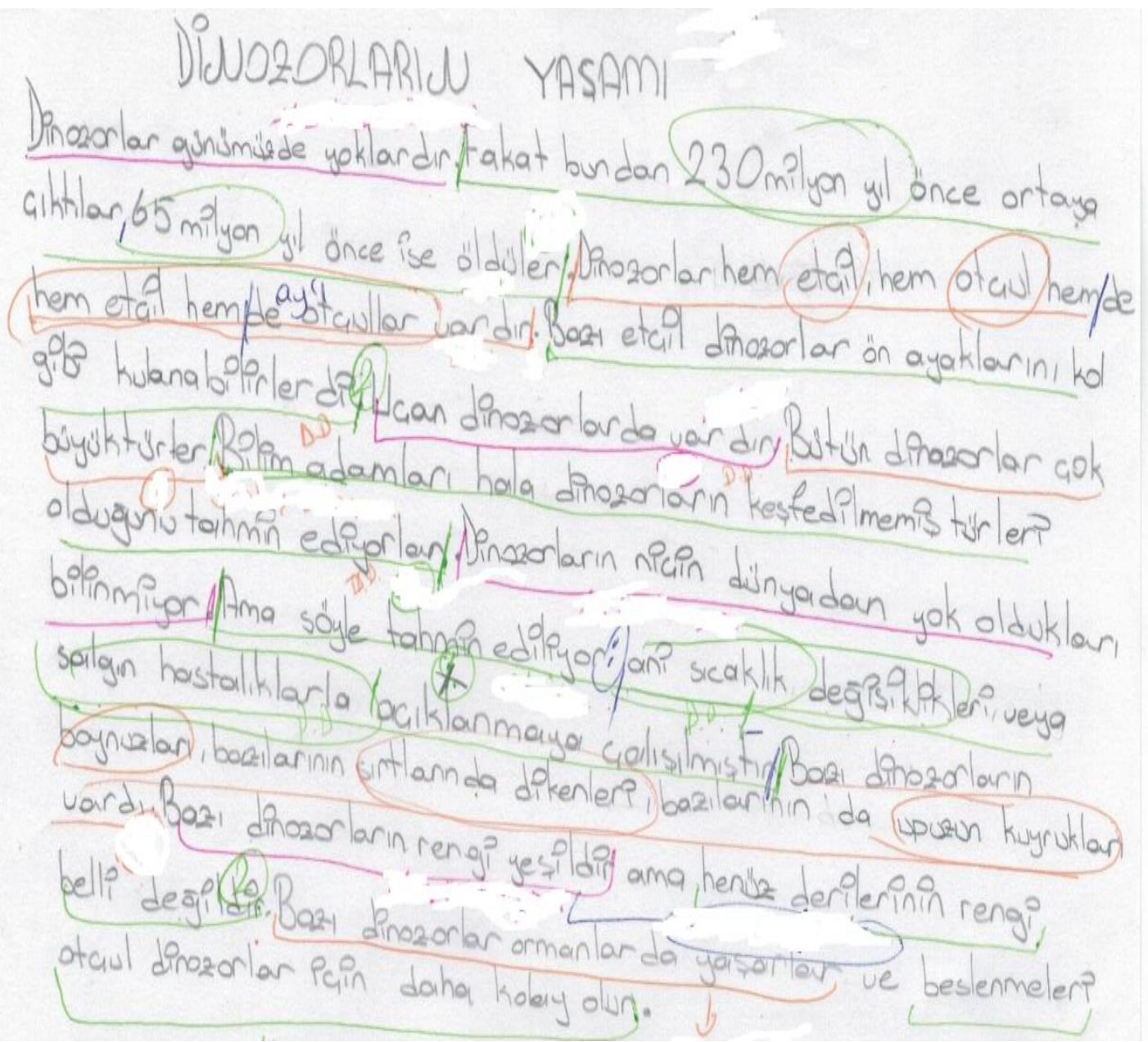

Şekil 8. Ayrı Yazılması Gereken Bağlaçları Birleşik Yazma Sorunu Olan Bir Öğrenci Metni

Şekil 8'de öğrencinin 'de' bağlacının yazımında sorun yaşadığı görülmektedir. Ancak sorunun sürekli görülmemesi, ("bazılarının da” ifadesinde ayrılmış) öğrencinin kuralı bildiğini ancak her yerde dikkat etmediğini düşündürmektedir.

Noktalama işaretleriyle ilgili tespit edilen sorunlar ise şunlardır: Gerekli yerde virgül kullanmama ( $f=14)$, gerekli yerlerde nokta kullanmama $(f=29)$, iki nokta kullanılması gereken yerde kullanmama $(f=7)$ ve gerekli yerde kesme işareti kullanmama $(f=6)$, noktalı virgül kullanılması gereken yerde kullanmama $(f=2)$, noktalı virgülü yanlış kullanma $(f=2)$, soru işareti kullanılması gereken yerde kullanmama $(\mathrm{f}=2)$. Gerekli yerlerde nokta kullanmama sorununun bu kadar sık görülmesi dikkat çekici bir bulgu olmuştur.

\section{Okuma Sürecindeki Sorunlara iliş̧kin Bulgular}

Sentez metin oluşturma süreci, kaynak metinlerin okunması ve bu kaynaklardaki bilgilerden yararlanmaya dayandığı için öğrencilerin sentez metin yazma süreçleri ya da başarıları incelenirken okuma süreci de dikkate alınmalıdır. Çünkü doğru tekniklerle gerçekleştirilen dikkatli bir okuma süreci, sentez metin oluşturma becerisini de olumlu yönde etkileyecektir. Bu anlamda öğrencilerin kullandıkları kaynak metinler ve not kâğıtları da doküman incelemesine tâbi tutulmuştur. Okuma metinleri ve not kâğıtlarıyla ilgili bulgular aşağıda sunulmuştur:

Öğrencilerin sentez metinlerini oluşturmak için kullandıkları (okudukları) kaynak metinler incelendiğinde çoğunluğunun metin yazarken kullanılacak bilgilerden bazılarının altını çizme ( $f=32)$, önemli bazı kelime ve kavramların altını çizme $(f=5)$ ve kenar boşluklarına notlar alma $(f=1)$ teknikleri kullandıkları görülmüştür. Ancak istedikleri gibi ek kâğıt kullanabilecekleri belirtilmesine rağmen hiçbir öğrenci not almak için fazladan kâğıt kullanmamıştır. 


\section{Tartışma ve Sonuç}

7. sınıf öğrencilerinin sentez metin yazma sürecindeki sorunlarını, oluşturdukları metinlerden, özgün metinlerini oluşturmak için yararlandıkları kaynak metinlerden ve not kâğıtlarından hareketle inceleyen bu araştırmada ulaşılan sonuçlar aşağıda sunulmaktadır.

Öğrencilerin metnin genel organizasyonu ile ilgili sorunları incelendiğinde şu sonuçlara ulaşılımıştır:

Giriş bölümüyle ilgili olarak öğrencilerden bazılarının içerik ve/ya da biçimsel açıdan giriş bölümünü karşılayan bir başlangıç yapamadığı, giriş bölümü yazanların ise bu bölümün özelliklerine uygun giriş yazmada başarısız olduğu görülmüştür. Gelişme bölümüyle ilgili sorunlar incelendiğinde, öğrencilerin bu bölümde konuyu detaylandırma, bölümü paragraflara ayırma ve tutarlılık açısından sorunlar yaşadıkları görülmüştür. Sonuç bölümüyle ilgili sorunlara bakıldığında, bazı öğrencilerin metnin sonuç bölümünü yazmadığı, bazı öğrencilerin ise metinde ele alınanları toparlayıcı ve işlevine uygun bir sonuç yazamadıkları tespit edilmiştir. Giriş, gelişme ve sonuç bölümlerinin organizasyonuyla ilgili sorunlar incelendiğinde öğrencilerin bu bölümler için ayrı paragraflar oluşturamadıkları ve bölümler arasında tutarlı bir bağlantı kuramadıkları görülmüştür. Başlık yazma ile ilgili sorunlar incelendiğinde de öğrencilerden bazılarının başlık yazmadığı, bazılarının da anlamlı, özgün ve içeriğe uygun başıı oluşturamadıkları tespit edilmiştir.

Metnin genel organizasyonuyla ilgili sonuçlara bakıldığında, sentez metin oluşturma sürecinde öğrencilerin metin organizasyonuyla ilgili eksiklerinin olduğu görülmektedir. Read (2000) tarafından 24 birinci ve ikinci sınıf öğrencisiyle yapılan durum çalışmasında öğrencilerin kaynaklardan yazma sürecinde metin organizasyonuna özen gösterdikleri tespit edilmiştir. Özenli ve bilinçli bir yazma sürecinin başarıyı artıracağı tartışmasız bir gerçektir. Ayrıca sentez yazma ile ilgili etkili bir eğitim verildiği takdirde, öğrencilerin metin organizasyonu başarılarının arttığı çeşitli çalışmalarda (Boscolo, Arfé ve Quairsa, 2007; Dovey, 2010; Luo, 2018) ortaya koyulmuştur. Mevcut çalışmadan elde edilen sonuç, öğrencilerin metin bölümlerinin işlevlerini yeterince bilmemelerinden ya da bilgilerini uygulayamamalarından kaynaklanıyor olabilir. Ayrıca araştırmacı yazma sürecinde motivasyonu artırmaya yönelik tedbirler alsa da, öğrencilerin yazma sürecinde özensiz olmalarından dolayı da bu sonuç ortaya çıkmış olabilir.

Öğrencilerin metin yapısı oluşturma ile ilgili sorunları incelendiğinde şu sonuçlara ulaşılmıştır:

Öğrencilerden bazıları, metin yazarken kaynak metinlerdeki temel düşüncelerden hiç yararlanmamış, bazı öğrenciler ise çok az yararlanmıştır. Ek olarak, öğrencilerden pek çoğu metin yapısı oluştururken, temel düşünceler dışındaki destekleyici düşüncelere oldukça az yer vermişlerdir. Bilgilendirici bir metinde açıklama, sınıflama, örnekleme, problem-çözüm, karşılaştırma vb. yapılar bir arada bulunabilir. Bilgilendirici metinlerde farklı yapıların nasıl ve nerede kullanılacağı metnin planıyla ilgilidir. Bu açıdan bakıldığında, öğrencilerin metinlerinde farklı yapılara yer verdiği görülmektedir. Ancak temel ve destekleyici bilgilerle birlikte, metni planlama ve metin yapısı oluşturma konusunda yeterli düzeyde olmadıkları sonucuna ulaşılabilir. Bu sonuç, öğrencilerin metin yapısı türleri ve bu türleri kullanarak metnin nasıl planlanacağıyla ilgili bilgi sahibi olmamalarından kaynaklanmış olabilir. Çünkü araştırmalar (González-Lamas, Cuevas ve Mateos, 2016; Zhang, 2012) iyi organize edilmiş sentez metin yazma eğitimiyle metin yapısı oluşturma başarısının geliştirilebileceğini göstermektedir.

Öğrencilerin içerik ve anlatımı düzenlemeyle ile ilgili sorunları, kaynak metinlerdeki bilgilerin aktarımı, tutarlılık ve üslup açısından ortaya çıkmaktadır. Kaynak metinlerdeki bilgilerin aktarımıyla ilgili sorunlar; kopyalama, bilgilerin sunum sırası, anlaşılırlığı ve aktarım şekliyle ilgilidir. Tutarlılık ile ilgili belirlenen sorunlar; yönlendirici sözcüklerin ve bağlantı cümlelerinin kullanımı, paragrafların kendi içindeki tutarılı̆̆ı ve çelişen bilgi kullanımıyla ilgilidir. Üslupla ilgili sorunlar; bilgilendirici metin üslubuna uygun yazamama ve akademik dil ile olay anlatımı dilini birlikte kullanma sorunlarıdır. Çeşitli araştırmalarda (Boscolo vd., 2007; Zhang, 2012) içerik ve anlatımla ilgili hususların eğitimle geliştirilebildiği ortaya koyulmuştur. Read (2000) tarafından yapılan araştırmada da öğrencilerin metin yazarken içerikle ilgili olarak neyi yazıp neyi yazmayacaklarını belirlemeye ve fikir üretmeye odaklandıkları tespit edilmiştir. Ancak mevcut araştırmada metinler değerlendirildiğinde, öğrencilerin içerik oluşturma ve anlatımla ilgili eksikleri olduğu gözlenmektedir. Belirlenen bu sorunlar, öğrencilerin bir metin oluşturmak için kaynaklardan yararlanma konusunda iyi bir eğitim almamış olmalarından; 
içeriğin tutarlılık ve üslup açısından nasıl düzenlenmesi gerektiğini bilmemelerinden ya da bilgilerini uygulayamamalarından kaynaklanmış olabilir. İçerik ve anlatımın düzenlenmesi, bir metnin niteliğini belirleyen önemli ölçütlerden biridir.

Öğrencilerin kaynak metinlerin kullanımı ile ilgili sorunları, bilgi seçimi ve kaynak metinlerdeki bilgilerin kullanım şekli başlıklarında görülmüştür. Bilgi seçimiyle ilgili olarak öğrencilerin, önemli bilgilerin seçiminde ve konunun farklı boyutlarına yer vermede sorun yaşadıkları tespit edilmiştir.

Kaynak metinlerdeki bilgilerin kullanımıyla ilgili olarak da öğrencilerin, bir temel düşünce etrafında şekillenen paragraflar oluşturamama, bilgileri eksik ya da yanlış aktarma, bilgilerin detaylandırıması ve ilişkilendirilmesi ile ilgili sorunlar yaşadıkları tespit edilmiştir. Yapılan araştırmalar, verilen eğitimlerin öğrencilerin metinlerinde kaynak kullanma becerilerini geliştirdiğini göstermektedir (bkz. Cumming, Lai ve Cho, 2016). Benzer şekilde, Martínez, Mateos, Martín ve Rijlaarsdam'ın (2015) 6. sınıf öğrencilerinin sentez yazma başarılarını geliştirmek üzere yaptıkları öntest-sontest deney ve kontrol gruplu araştırmada da, deney grubu öğrencilerinin kaynak metinlerle yazdıkları metin arasındaki etkileşimin eğitim sonrasında arttığı tespit edilmiştir. Bu durumda, mevcut araştırmada ortaya çıkan sonuca göre öğrencilerin kaynak metinlerden yararlanma ile ilgili yeterli bir eğitim almadıkları ya da öğretilenleri uygulayamadıkları düşünülebilir.

Öğrencilerin dil kullanımı ile ilgili sorunları, cümle anlamı, anlatım bozuklukları, yazım ve noktalama kurallarıyla ilgilidir. Cümle anlamıyla ilgili olarak öğrencilerin anlam sorununa yol açacak dil bilgisel hatalar yaptıkları ve cümledeki anlamı tam oluşturamadıkları sonucuna varılmıştır. Anlatım bozukluklarıyla ilgili olarak, ek kullanımı, kelime kullanımı ve cümlenin ögeleriyle ilgili anlatım bozuklukları yaptıkları sonucuna varılmıştır.

Yazım ve noktalamayla ilgili olarak öğrencilerin, bağlaçların yazımı, büyük harf kullanımı, kelime ve heceyle ilgili hatalarla, çeşitli noktalama işaretlerinin kullanımıyla ilgili sorunlar yaşadıkları tespit edilmiştir. Yazım ve noktalama öğrencilerin eğitim hayatlarına başladıkları ilk yıllardan itibaren eğitimini aldıkları bir alandır. Öğrencilerden yazma sırasında yazım ve noktalamaya ilişkin kurallara özen göstermeleri beklenir. Nitekim Read (2000) tarafından yapılan araştırmada da öğrencilerin biçimle ilgili olarak el yazısı, sayfa sınırları, uzunluk ve yazı düzeniyle birlikte yazım-noktalama ve cümle yapısına da dikkat ettikleri tespit edilmiştir. Mevcut araştırmada, öğrencilerin yazım ve noktalama ile ilgili sorunlarının kuralları bilmemelerinden değil, yazım sırasında özen göstermemelerinden kaynaklanmış olabileceği düşünülmektedir. Bir başka sebep de öğrencilerin yazma sonrası, gözden geçirme ve düzeltme aşamasında özensiz olmaları ya da yazılarını hiç kontrol etmemeleri olabilir.

Öğrencilerin okuma sırasında işaretleme ve not almaya ilişkin uygulamalarından elde edilen bulgular incelendiğinde, öğrencilerin okuma sırasında çoğunlukla bilgilerin altını çizdiği görülmüştür. Öğrencilerden sadece birinin okurken kenar boşluklarına not alması, hiçbir öğrencinin not almak için ek bir not kâğıdından yararlanmaması dikkat çekici bir sonuç olmuştur. Öğrencilere yazma öncesinde, verilen metinlerdeki bilgilerden yararlanarak metin yazacakları belirtilmesine rağmen not almamaları, okuma sırasında not alma becerilerinin ve bu bilincin gelişmemiş olmasıyla ilgili olabilir. Özçakmak (2015), not almanın bilgileri hatırlamayı kolaylaştırma, akademik başarıyı artırma, yazma alışkanlığı edinme, dikkati toplamayı kolaylaştırma gibi yararları olduğunu belirtmiştir. Buna rağmen, öğrencilerin bu açıdan eksiklerinin bulunması dikkate alınması gereken bir sonuçtur.

\section{Öneriler}

Öğrencilerin yazdıkları metinlerin ve kaynak olarak verilen okuma metinlerindeki uygulamalarının analizinden elde edilen sonuçlardan hareketle şu önerilerde bulunulabilir:

1. Gerek sentez metin oluşturma eğitiminde gerek genel yazma eğitiminde, öğrencilere metnin giriş, gelişme ve sonuç bölümlerinin işlevleri ve bu bölümleri nasıl oluşturmaları gerektiği uygulamalı bir biçimde öğretilmelidir.

2. Örnek bilgilendirici metinler üzerinden, bilgilendirici bir metnin yapısının nasıl planlanacağı, bu planda hangi yapısal özelliklerin bulunabileceği hem okuma hem de yazma eğitimleri sırasında öğretilmelidir. 
3. Sentez metinlerin içeriği ve anlatımı, yararlanılan kaynak metinlerden büyük ölçüde etkilenmektedir. Bu nedenle, eğitim sırasında içerik ve anlatımı düzenlerken kaynak metinlerin kullanımı ve buradaki bilgilerin aktarımı, tutarlılık ve üslup ile ilgili hususların eğitimine özen gösterilmelidir.

4. Sentez metin eğitiminin temel taşlarından biri olan kaynak kullanımının öğretilmesinde şu noktalara dikkat edilmelidir:

- Öğrencilere hangi bilgileri seçeceklerini, doğru/önemli bilgiye nasıl karar verecekleri öğretilmelidir.

- Metinde tutarlıığı bozmayacak şekilde, bir konunun farklı yönlerinin ele alınması gerektiği öğretilmelidir.

- Bilgilerin doğru yerde ve doğru şekilde nasıl kullanılacağı öğretilmelidir.

5. Yazma sırasında dilin anlamsal ve mekanik özelliklerine özen gösterme alışkanlığı kazandırılmalıdır.

6. Öğrencilere, okuma sürecinde kullanmaları için önemli bilgilerin altını çizme, gerekli yerlerde işaretlemelerden yararlanma, not alma vb. teknikler öğretilmelidir.

7. Okuma stratejilerinden yararlanma becerisi kazandırılmalıdır.

\section{Kaynaklar}

Asención, Y. (2004). Validation of reading to write assessment tasks performed by second language learners (Doctoral Dissertation). Proquest Dissertations \& Theses veri tabanından edinilmiştir. (UMI no. 3138530)

Beal, J. A. (2010). Toward a definition assesment and measure of synthesis of multiple texts (Doctoral Dissertation). Proquest Dissertations \& Theses veri tabanından edinilmiştir. (UMI no. 3438029)

Boscolo, P., Arfé, B., \& Quarisa, M. (2007). Improving the quality of students' academic writing: An intervention study. Studies in Higher Education, 32(4), 419-438.

Bråten, I., \& Strøms $\varnothing$, H. I. (2010). When law students read multiple documents about global warming: Examining the role of topic-specific beliefs about the natüre of knowledge and knowing. Instructional Science, 38(6), 635-657.

Can, T. (2012). Dinozorların dünyası. Bilim Çocuk, 169, s. 38-39. (EBA'dan erişilmiştir.)

Creswell, J. W. (2017). Araştırma deseni nitel, nicel ve karma yöntem yaklaşımları. (Research design qualitative, quantitative and mixed methods approaches). (Çev. Ed. Selçuk Beşir Demir). Ankara: Eğiten Kitap.

Cumming, A., Lai, C., \& Cho, H. (2016). Students' writing from sources for academic purposes: A synthesis of recent research. Journal of English for Academic Purposes, 23, 47-58.

De La Paz, S., \& Felton, M. K. (2010). Reading and writing from multiple source documents in history: Effects of strategy instruction with low to average high school writers. Contemporary Educational Psychology, 35, 174-192. doi:10.1016/j.cedpsych.2010.03.001

Dovey, T. (2010). Facilitating writing from sources: A focus on both process and product. Journal of English for Academic Purposes, 9, 45-60.

Emehatsion, T. G. (1998). Investigation and explanation of major factors affecting academic writing: Using multiple sources (Doctoral Dissertation). Proquest Dissertations \& Theses veri tabanından edinilmiştir. (UMI no. 10079562)

Gebril, M. A. (2006). Independent and integrated academic writing tasks: A study in generalizability and test method (Doctoral Dissertation). Proquest Dissertations \& Theses veri tabanından edinilmiştir. (UMI no. 3248012)

Gil, L., Bråten, I., Abarca, E. V., \& Strøms $\varnothing$, H. I. (2010). Summary versus argument tasks when working with multiple documents: Which is better for whom?. Conteporary Educational Psychology, 35, 157-173.

Goldman, S. R. (2004). "Cognitive aspects of constructing meaning through and across multiple texts". In N. Shuart-Faris and D. Bloom (Eds.), Uses of Intertextuality in classroom and educational research (pp. 317-351). Greenwich, CT: Information Age Publishing. 
González-Lamas, J., Cuevas, I., \& Mateos, M. (2016). Arguing from sources: Design and evaluation of a programme to improve written argumentation and its impact according to students' writing beliefs/Argumentar a partir de fuentes: diseño y evaluación de un programa para mejorar la argumentación escrita y su impacto en función de las creencias acerca de la escritura académica que mantienen los estudiantes. Infancia y Aprendizaje, 39(1), 49-83.

Göçer, A. (2018). Yazma eğitimi-yazma uğraşı: Yazı nasıl yazılır?, Nasıl yazar olunur? 3. baskı, Ankara: Pegem Akademi.

Graham, S., \& Harris, K. R. (2013). Designing an effective writing program. In Steve Graham, Charles A. MacArthur, Jill Fitzgrald (Eds.), Best practices in writing instruction (pp. 3-25). NewYork: The Guilford Press.

Hammann, L. A., \& Stevens, R. J. (2003). Instructional approaches to improving students' writing of compare-contrast essays: An experimental study. Journal of Literacy Research, 35(2), 731-756. https://journals.sagepub.com/doi/pdf/10.1207/s15548430jlr3502_3

Holmberg, B. H. (1998). Developmental students' orchestration of strategies in an integrated reading and writing task (Doctoral Dissertation). Proquest Dissertations \& Theses veri tabanından edinilmiştir. (UMI no. 9836414)

Karadağ, R. (2016). Yazma eğitimi. F. Susar Kırmızı (Ed.), ilk ve ortaokullarda Türkçe öğretimi içinde (s. 163-210). Ankara: Anı Yayıncılık.

Kim, J. Y. (2008). Development and validation of an ESL diagnostic reading to write test: An effect-driven approach (Doctoral Dissertation) Proquest Dissertations \& Theses veri tabanından edinilmiştir. (UMI no. 3337823)

Kirkpatrick, L. C. (2012). Students' strategies for writing arguments from online sources of information. (Doctoral Dissertation) University of Western Ontario, London, Ontario, Canada.

Kirkpatrick, L. C. \& Klein, P. D. (2009). Planning text structure as a way to improve students' writing from sources in the compare-contrast genre. Learning and Instruction, 19, 309-321.

Luo, L. (2018). Helping students SOAR to success on synthesis writing (Doctoral Dissertation). Proquest Dissertations \& Theses veri tabanından edinilmiştir. (UMI no. 10748131)

Martínez, I., Martín, E., \& Mateos, M. (2011). Enseñar a leer y escribir para aprender en la Educación Primaria [Teaching to read and write to learn in primary education] Cultura Y Educacion, 23(3), 399-414. doi:10.1174/113564011797330306

Martínez, I., Mateos, M., Martín, E., \& Rijlaarsdam, G. (2015). Learning history by composing synthesis texts: Effects of an instructional programme on learning, reading and writing processes, and text quality. Journal of Writing Research, 7(2), 275-302.

Mateos, M., Martín, E., Cuevas, I., Villalón, R., Martínez, I., \& González-Lamas, J. (2018). Improving written argumentative synthesis by teaching the integration of conflicting information from multiple sources. Cognition and Instruction, 0(0), 1-20. DOI: 10.1080/07370008.2018.1425300

Mateos, M., Martín, E., Villalón, R., \& Luna, M. (2008). Reading and writing to learn in secondary education: Online processing activity and written products in summarizing and synthesizing tasks. Reading and Writing, 21, 675-697.

Mateos, M., \& Solé, I. (2009). Synthesising Information from various texts: A Study of procedures and products at different educational levels. European Journal of Psychology of Education, 24, 435451.

Mather, N., Wendling, B. J., \& Roberts, R. (2009). Writing assessment and instruction for students with leaning disabilities. San Francisco: Jossey-Bass.

McCutchen, D. (2008). Cognitive factors in the development of children's writing. In C. A. MacArthur, S. Graham, \& J. Fitzgerald, J. (Eds.), Handbook of writing research (pp.115-130). New York: Guilford Press.

McMackin, M. C. (1994). Discourse synthesis: The role of task Impression, goal setting, organization and connectivity when writing from sources (Doctoral Dissertation). University of Massachusetts Lowell, Massachusetts. 
Nash, J. G. (1990). Writing from sources: A structure-mapping model (Doctoral Dissertation). Proquest Dissertations \& Theses veri tabanından edinilmiştir. (UMI no. 9111455)

Nelson, N. (2009). The reading-writing nexus in discourse research. In Charles Bazerman (Ed.), Handbook of research on writing (pp. 534-553). New York: Taylor \& Francis Group.

Özçakmak, H. (2015). Türkçe öğretmeni adaylarının not alarak dinlemede özetleme stratejilerini kullanma becerileri (Doktora tezi). Yükseköğretim Kurulu Ulusal Tez Merkezi'nden edinilmiştir. (Tez No. 388180).

Read, S. (2000). First and second graders writing information texts: An interpretive case study (Doctoral Dissertation). Utah State University, Logan, Utah.

Reynolds, G.A. (2006). Teaching composing from sources to middle grade students (Doctoral Dissertation). Proquest Dissertations \& Theses veri tabanından edinilmiştir. (UMI no. 3213583)

Risemberg, R. (1993). Self-regulated strategies of organizing and information seeking when writing expository text from sources (Doctoral Dissertation). Proquest Dissertations \& Theses veri tabanından edinilmiştir. (UMI no.9325139)

Schlumberger, A. L. (1991). The effects of elaboration on community college students' execution of a reading-writing task (Doctoral Dissertation). Proquest Dissertations \& Theses veri tabanından edinilmiştir. (UMI no. 9200024)

Segev-Miller, R. (2004). Writing from sources: The effect of explicit instruction on college students' processes and products. L1-Educational Studies in Language and Literature, 4, 5-33.

Solé, I., Miras, M., Castells, N., Espino, S., \& Minguela, M. (2013). Integrating infomation: An analysis of the processes involved and the products generated in a written synthesis task. Written Communication, 30(1), 63-90.

Spivey, N. N. (1983). Discourse synthesis: Constructing texts in reading and writing (Doctoral Dissertation). Proquest Dissertations \& Theses veri tabanından edinilmiştir. (UMI no. 8329876)

Spivey, N. N. (1990). Transforming texts: Constructive processes in reading and writing. Written Communication, 7(2), 256-287.

Spivey, N. N. (1997). The constructivist metaphor reading, writing and the making of meaning. San Diego, CA: Academic Press.

Strøms $\varnothing$, H. I., Bråten, I., \& Samuelstuen, M. S. (2003). Students' strategic use of multiple sources during expository text reading: A longitudinal think-aloud study. Cognition and Instruction, 21(2), 113-147.

Tok, G. (1998). Geçmişin gerçek devleri dinozorlar. Bilim Çocuk, 10, s. 12-13. (EBA'dan erişilmiştir.)

Tolchinsky, L. (2008). Emergence of writing. In C. A. MacArthur, S. Graham, \& J. Fitzgerald (Eds.), Handbook of writing research (pp.83-95). New York: Guilford Press.

Uğur, F. (2017). Ortaokul 7. sınıf öğrencilerinin bilgilendirici metin yapısı unsurlarını belirleme düzeyleri. Mustafa Kemal Üniversitesi Sosyal Bilimler Enstitüsü Dergisi, 14(39), 200-222.

Watanabe, Y. (2001). Read to write tasks for the assesment of second language academic writing skills: Investigating text features and rater reactions (Doctoral Dissertation). Proquest Dissertations \& Theses veri tabanından edinilmiştir. (UMI no. 3017414)

Yıldırım, A., \& Şimşek, H. (2016). Sosyal bilimlerde nitel veri analizi. Ankara: Seçkin Yay.

Zhang, C. (2012). Effect of instruction on english as a second language students' discourse synthesis writing (Doctoral Dissertation). Arizona State University, Flagstaff, Arizona.

Zhao, R., \& Hirvela, A. (2015). Undergraduate ESL students' engagement in academic reading and writing in learning to write a synthesis paper. Reading in a Foreign Language, 27(2), 219-241.

\section{Extended Abstract}

\section{Introduction}

Writing a synthesis text means the process in which writers create their authentic texts by utilising information from more than one source and their prior knowledge (see Spivey, 1990, 1997). At this point, an individual writes a text by being in the position of both a reader and a writer and going through the processes of selection, organisation, and combination. Accordingly, the aim of this research was to examine seventh grade students' problems during the process of writing a synthesis 
text considering the texts written by the students, source texts utilised by the students for writing their authentic texts, and their notepapers. In accordance with this purpose, answers for the following questions were sought:

1. What kind of problems were found in the synthesis texts written by the students?

2. What kind of exercises were performed by the students on the source texts while they were writing the synthesis texts?

3. What kind of note-taking exercises were performed by the students while writing the synthesis texts?

\section{Method}

The case study design, one of the qualitative research methods, was used in the study. The participants of the research consisted of 51 students studying at the seventh grade of a public school in the city centre of Hatay during 2017-2018 academic year.

During the data collection process, two informative texts about the characteristics of dinosaurs were presented to the students. The students were asked to write their own texts on the same topic by benefiting from the information in these two texts. Moreover, it was also stated that when they wished, they could take additional papers as much as they want in the processes of reading and writing. This practice was completed in a period of two lessons.

The document analysis method was used in the data analysis. The documents planned to be analysed in the study were as follows: Synthesis texts written by the students, source texts, and notepapers of the students.

The synthesis texts written by the students were analysed in terms of the dimensions of general organisation of the texts, creating texts' structure, organising content and expression, using source texts, and use of language. The problems identified for these dimensions were recorded separately and their frequency values were given during the analysis.

The techniques that could be used during the reading process were determined before starting the analysis of the source texts. Accordingly, the criteria based in the document analysis were as follows:

1. Underlining important points

2. Circling important words and terms

3. Benefiting from markings

4. Taking notes from the important parts/ Taking notes on the margins

It was planned to record also any other application if encountered apart from these criteria and to give frequency values of all the problems.

It was intended to perform document analysis for determining how the students took notes on notepapers while preparing for the writing process. In relation to this, it was decided to examine how the information to be used in the texts was noted and what kinds of practices were performed for planning the content and text organisation.

\section{Result and Discussion}

Related to the general organisation of the text, it was detected that the students had difficulties in writing the introduction section, writing the development section, writing the conclusion section, and organising the introduction, development, and conclusion sections. When the results related to the general organisation of the texts were evaluated as a whole, it was seen that the students had deficiencies in text organisation in the process of writing a synthesis text. The reason for this result might be that students did not know the functions of the text sections enough or they could not apply their knowledge.

Related to the creating text structure, it was seen that some of the students had problems of never benefiting or slightly benefiting from the basic ideas in the source texts while writing the texts. Additionally, it was detected that most of the students included rather few supportive ideas apart from the basic ideas while structuring the text. When the results were considered, it was observed that 
students included different structures in their texts. However, it could be concluded that they were not sufficient in text planning and text structuring with basic and supportive information. This result might be explained with that students did not have knowledge of text structure types and the ways of how structuring a text using these types.

It was detected that students' problems about the organising content and expression occurred in terms of transmission of information in the source texts, consistency, and style. These identified problems could result from students' not having a good training on using sources for writing a text, not knowing how to organise the content in terms of consistency and style, or not implementing their knowledge.

The problems that the students had related to using the source texts were seen in the titles of data selection and usage of information in the source texts. In this case, it can be thought that the students do not receive sufficient training on using source texts or may not practice what they learnt according to the results obtained in this study.

The students' problems related to language use were about meaning of a sentence, ambiguities, and spelling and punctuation rules. It is thought that it might be the reason of the students' problems about language that they might not care for rules during writing instead of not knowing these rules. Another reason could be that the students might be careless during the phase of revision and improving or might not check their texts after they wrote them.

It was seen that the students usually underlined information while reading when the findings obtained from the implementations related to marking and taking note during this stage were examined. It was a remarkable outcome that only one of the students took notes on page margins while they were reading, and no students used an extra notepaper for taking note. The reason for students' not taking note before writing although it was stated that they would write a text using the information from the text given might be that their skills of taking note while reading and awareness related to this were underdeveloped. 